\title{
Dimension Dependence of Boundary-Layer Transfer Coefficient of Water-Vapor for Flat Plant Leaf
}

\author{
Tetsuya HASEBA and Daijiro ITo \\ (Division of Agricultural Meteorology, College of Agriculture, \\ Ehime University, Matsuyama 790, Japan
}

\begin{abstract}
A fundamental function of the coefficient of heat/mass transfer across a boundary layer on a plant leaf for forced convection was evaluated in relation to the leaf dimension. The average transfer coefficients on a model-leaf were obtained from the measurements of water evaporation from the surface of flat rectangular plates with various lengths and widths from 1 to $32 \mathrm{~cm}$. The surface of the model-leaf was set in parallel with the air flow in a wind tunnel.

The average coefficients were proportional to the square root of the wind speed in a laminar region. For plates with relatively small lengths in the direction of the flow, compared to their transverse widths, the observed coefficients were in good agreement with the theoretical ones. For plates with lengths more than a critical value, however, the observed coefficients were larger than the theoretical ones. In a width-fixed model-leaf, the ratio of the observed coefficient to the theoretical one increased with an increase in length, whereas in a length-fixed leaf it decreased with increasing width.
\end{abstract}

A realistic transfer coefficient for forced convection was formulated as a function of the length and width of model-leaf and wind speed.

\section{Introduction}

Much research has been done on heat and mass transfer coefficients for a plant leaf and/or a model-leaf boundary-layer (Monteith, 1973), and several features of the coefficient have been revealed, including complicated ones under the field conditions (Parlange and Waggoner, 1972; Pearman et al., 1972; Haseba, 1975). Whereas, in the fundamental features, there have still been left some distinguished problems. One of the most important features that are left for study is the relationship between the transfer coefficient and the leaf dimension, and others are the effect of buoyancy on the forced convection transfer over a very low wind speed range, the separation of the leaf-internal transfer coefficient from the boundary-layer one, and so on.

In the present paper, the leaf-dimension dependence of the forced convection transfer coefficient

Read at a Chugoku-Shikoku Chapter Meeting, Tokushima, 7 February, 1980.

Received 21 April, 1980. is studied. As well known, the approximate boundary-layer theory has the assumption that heat and mass are transferred in the direction perpendicular to the plane surface, across the boundary-layer; the average transfer coefficient on a flat plate is proportional to the square root of the wind speed and inversely proportional to the square root of the plate-length in the direction of the air flow but independent of the transverse width. However, the transfer coefficient for a plant leaf with a limited area may not be only a function of the length but also of the width, owing to the transport along the surface at the edge.

Raschke (1956) and Gates (1968) described that the boundary-layer transfer coefficients were inversely proportional to lower exponents of the leaf-length than 0.5. But the deriving data for the function had not been represented, in both papers. In recent years, Balding and Cunningham (1976) found some experimental equations for the average heat transfer coefficient on a flat rectangular plate as a model-leaf. Haseba and Ito (1976) recognized 
larger coefficients than the theoretical ones for vapor transfer from an elongated model-leaf, and Haseba (1977) showed the inverse proportionality of the 0.59 power of the dimension for considerably small circular and square shaped model-leaves. Yabuki and Harazono (1978) also observed the width dependence of the boundary-layer thickness for model-leaves inclined to the air flow. Unfortunately, there are some discrepancies among the results in the previous papers.

Therefore, with the purpose to clarify the relationship between the transfer coefficient and the leaf dimension, measurements of evaporation were made for model-leaves of different dimensions.

\section{Experimental procedures}

Flat plates as leaf-models were squares and rectangulars with dimensions of $1,2,4,8,16$ and $32 \mathrm{~cm}$ in length in the direction of the air flow and $1,2,4,8,16$ and $32 \mathrm{~cm}$ in widths transverse to the flow. The thirty six plates were used for the measurements of evaporation in the laminar air flow in a wind tunnel. Inner plate material for the models was a plastic sheet and its thickness was $0.3 \mathrm{~mm}$ for relatively small evaporating surfaces and, $0.8 \mathrm{~mm}$ for large ones. The leading edge of a plate was formed into a knife edge. The plate surface from which water evaporated was covered with very thin paper placed over smooth blotting paper on the plate and contained enough water.

The plate was held with a thin iron-wire frame not to disturb the air flow in the test section of the wind tunnel, whose dimension was $40 \times 40 \mathrm{~cm}^{2}$. The leading edge of the plate was set in perpendicular to the flow direction and the wet surface was horizontal. The measurement included the wind speed (heated thermocouple anemometer), the dry and wet bulb temperatures (Assmann ventilated psychrometer), evaporating surface temperature (copper-constantan thermocouple $0.1 \mathrm{~mm}$ in diameter, which was cemented at the center of the plane surface). The amount of evaporation was measured by the weighing method. The experiments were conducted under the conditions of a certain constant air temperature of 18 to $25^{\circ} \mathrm{C}$ and a relative humidity of 30 to $40 \%$. The wind speed was adjusted from 0.5 to $8 \mathrm{~m} \mathrm{sec}^{-1}$.

The average value of forced convection vapor transfer coefficient on a plate $\left(D_{f, O B S}, \mathrm{~cm} \mathrm{sec}^{-1}\right)$ was evaluated using the following equation,

$$
D_{f, O B S}=w / \Delta C-D_{n},
$$

where $w$ is the evaporation rate in $\mathrm{g} \mathrm{cm}^{-2} \mathrm{sec}^{-1}$ and $\Delta C=C_{E}-c_{A}$, the difference of water vapor densities between the evaporating surface $\left(C_{F}\right.$, saturated at the surface temperature) and the air outside of the boundary-layer on the plate $\left(c_{A}\right)$ in $\mathrm{g} \mathrm{cm}^{-3}$. $D_{n}=0.27(G r \cdot S c)^{1 / 4} d / l_{n}$ is the mean vapor transfer coefficient for natural convection, which is used for the correction of the buoyancy effect on the convective transfer, where $G r$ and $S c$ are the Grashof and Schmidt numbers, respectively; $d$ is the molecular diffusivity of water vapor into air in $\mathrm{cm}^{2} \mathrm{sec}^{-1}$ and $l_{n}$, the mean dimension of the plate in $\mathrm{cm}$.

The theoretical transfer coefficient $\left(D_{f, T H}\right)$ for forced convection was estimated for the isothermal surface of a flat plate parallel to the air flow, with laminar boundary-layer;

$$
D_{f, T H}=0.664 \cdot S c^{1 / 3} R e^{1 / 2} d / l,
$$

which is rewritten as follows, at a reference temperature of $20^{\circ} \mathrm{C}$,

$$
D_{f, T H}=0.360(u / l)^{1 / 2},
$$

where $R e=u l / \nu$ is the Reynolds number; $u$, the wind speed $\left(\mathrm{cm} \mathrm{sec}^{-1}\right) ; \nu$, the dynamic viscosity of air $\left(\mathrm{cm}^{2} \mathrm{sec}^{-1}\right) ; l$, the plate-length along the flow $(\mathrm{cm})$.

A ratio $(\alpha)$ of the experimental transfer coefficient to the theoretical one is defined by

$$
\alpha=D_{f, O B S} / D_{f, T H} .
$$

\section{Results}

Because the evaporating surface was not heated, the surface temperature was nearly uniform; therefore, the effect of the temperature distribution was neglected on the convective transfer of water vapor (Haseba, 1973).

Fig. 1 shows some examples of the relationships between the average forced convection transfer coefficient and the wind speed for $16 \mathrm{~cm}$ wide plates of various lengths. In all cases, including the results not given in the figure, $D_{f}$ was proportional to the square root of the wind speed below a critical wind speed, above which $D_{f}$ showed the 


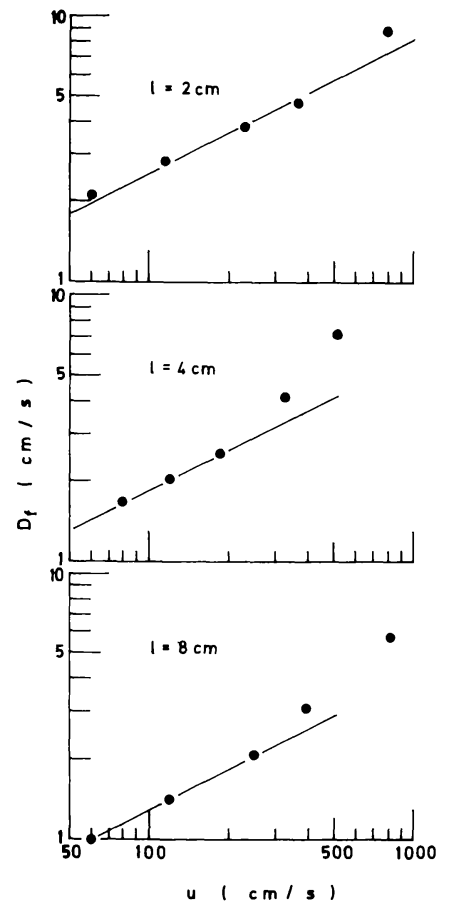

Fig. 1. Average water-vapor transfer coefficient for forced convection $\left(D_{f}\right)$ vs. wind speed $(u)$, for rectangular plates $16 \mathrm{~cm}$ in width. Thin real lines represent the theory and $l$, length in the direction of the air flow. transition from the feature in the laminar to the turbulent boundary-layer. For the $16 \mathrm{~cm}$ wide plates, the critical Reynolds number was about $1 \times 10^{4}$, however, it was different and complicated according to the plate dimension.

In the laminar region, as shown in Fig. 1, for the $16 \mathrm{~cm}$ wide plates of lengths 2,4 and $8 \mathrm{~cm}, D_{f}$ was in good agreement with the value estimated from the laminar boundary-layer theory.

On the other hand, for example of the $1 \mathrm{~cm}$ wide plate (Fig. 2), $D_{f}$ was much larger than the theory. The ratio of the observed transfer coefficient to the theoretical one $(\alpha)$ increased with increasing length, while for a model-leaf with a fixed-length it decreased with increasing width.

\section{Discussion}

Experimental results showed that the ratio $(\alpha)$ was not only related to the plate length along the air flow but also to the transverse width, in laminar region. Fig. 3 demonstrates the ratio $(\alpha)$ as a function of the length for each model-leaf of different widths.

The ratios increase with an increase in plate length for the plates of width $1,2,4$ and $8 \mathrm{~cm}$. The rates of the increase in the ratio with the

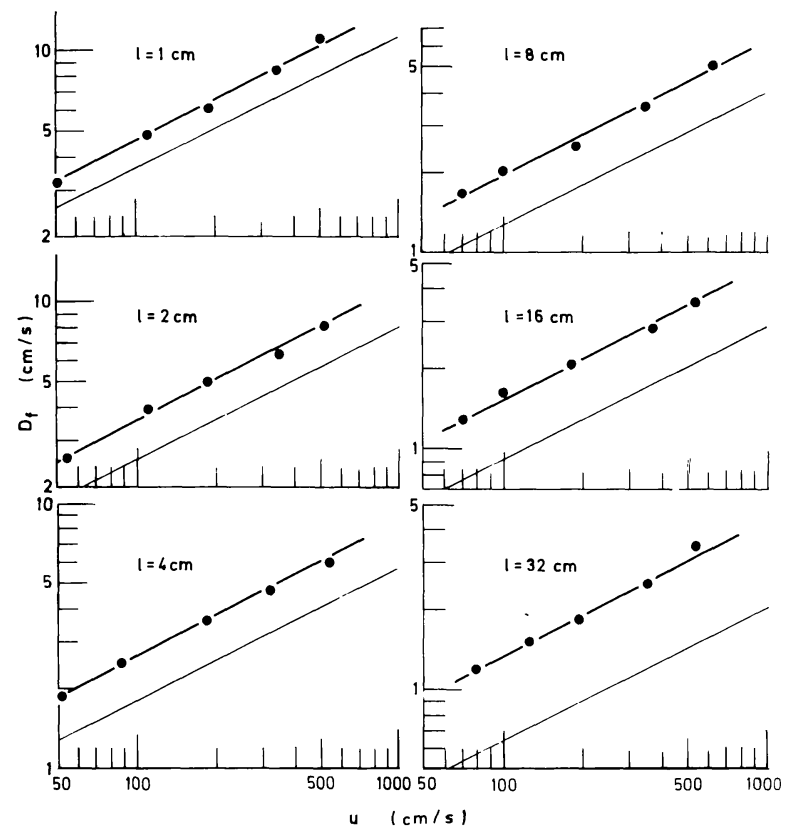

Fig. 2. Same as Fig. 1 , for plates $1 \mathrm{~cm}$ in width. Bold real lines represent the results of the measurements, and fine real lines, the theory. 


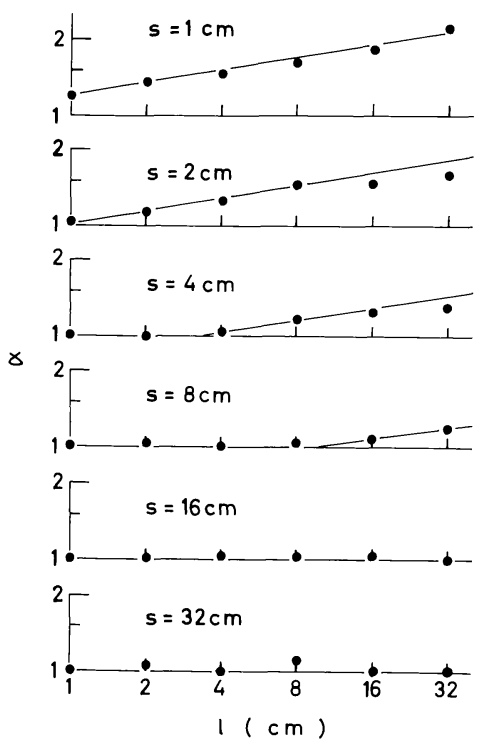

Fig. 3. Relation between the ratio of the observed transfer coefficient to the theoretical one $(\alpha)$ and the plate length $(l)$, against the plate with each width $(s)$.

length are nearly equal. The ratio is never below unity. The observed transfer coefficients agree well with the theoretical ones for some plates over the following ranges of the combination of the length and width; for the $4 \mathrm{~cm}$ wide plate, over the length range below 3 to $4 \mathrm{~cm}$; for the $8 \mathrm{~cm}$ wide plate, over the range below 8 to $9 \mathrm{~cm}$; for the 16 and $32 \mathrm{~cm}$ wide plates, over the whole range of lengths investigated.

On the other hand, the relationships between the ratio $(\alpha)$ and the plate-width show that the ratio decreases with increasing width for each plate under a range of width below a certain value, above which it becomes unity. This indicates that the theory and the observation agree when the width of the model-leaf is larger than a critical value. The critical leaf-width above which the ratio becomes unity are about 2, 3, 5, 7, 11 and $15 \mathrm{~cm}$ for model-leaves of lengths $1,2,4,8,16$ and $32 \mathrm{~cm}$, respectively. The fitted lines for the relation between the ratio and the width are lied parallel.

From the fact mentioned above, the ratio $(\alpha)$ can be formulated by

$$
\alpha=A l^{x} s^{y} .
$$

The numerical coefficient $(A)$ and the exponents $(x, y)$ in the above equation were evaluated by means of the least squares method using the data obtained here and from the experiments for elongated plates (Haseba and Ito, 1976) and for relatively small plates (Haseba, 1977). The equation is written as

$$
\alpha=1.20 l^{0.16} s^{-0.26} .
$$

The standard deviations of $A, x$ and $y$ were 0.04 , 0.01 and 0.02 , respectively.

Consequently, the average forced convection transfer coefficient for water vapor on a rectangular plate can be presented in the form of

$$
D_{f}=\alpha D_{f, T H}=0.797 S c^{1 / 3} R e^{1 / 2} d l^{-0.84} s^{-0.26},
$$

or

$$
\begin{aligned}
=0.34 u^{0.5} l^{-0.34} s^{-0.26}, & \text { at a reference tem- } \\
& \text { perature of } 20^{\circ} \mathrm{C} .
\end{aligned}
$$

The above equations are valid in a range of plate dimension expressed by $l>0.33 s^{1.6}$. The graphic illustration of this range of the dimension is given in Fig. 4.

For the plate $30 \mathrm{~cm}$ long and $1 \mathrm{~cm}$ wide, $D_{f}$ is as follows;

$$
D_{f}=0.138 u^{0.5},
$$

which is about 2.1 times as large as the theoretical value and slightly smaller than that obtained by Haseba and Ito (1976) for rice model-leaf. The difference is, however, as small as about $10 \%$.

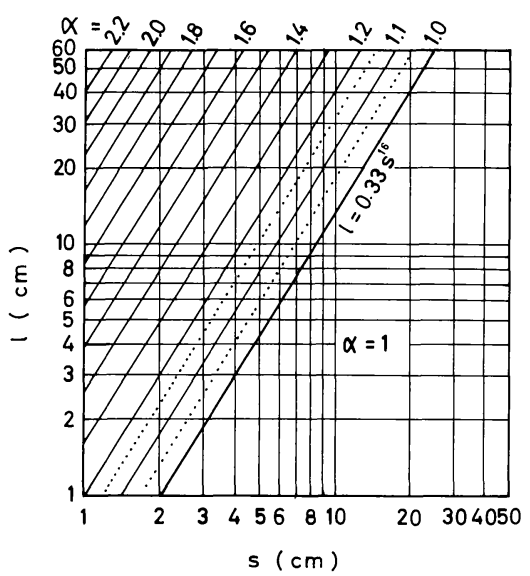

Fig. 4. Dimension region in which the observed transfer coefficients for forced convection are larger than the theoretical values. 
For square plates,

$$
D_{f}=0.34 u^{0.5} l^{-0.60} \text {, }
$$

that is in good agreement with the result for relatively small plates (Haseba, 1977).

In Fig. 5 are shown the boundary-layer transfer coefficients of water vapor obtained by several workers, as a function of the leaf-length in the direction of the air flow. Some of them have been converted from the heat transfer coefficients to
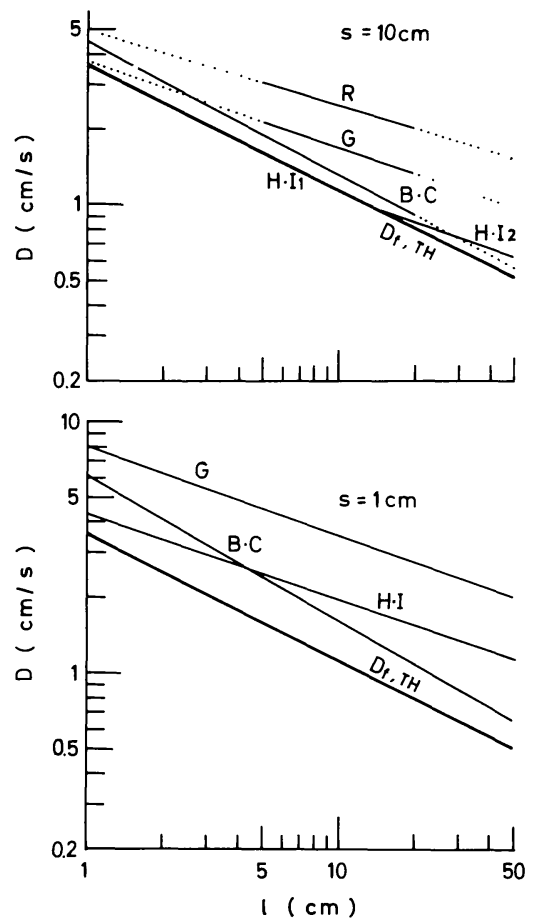

Fig. 5. Water vapor transfer coefficients for plates of widths $10 \mathrm{~cm}$ (upper part) and $1 \mathrm{~cm}$ (lower part) as a function of plate-length, at a wind speed of $1 \mathrm{~m} \mathrm{sec}^{-1}$ and a reference temperature of $20^{\circ} \mathrm{C}$.

For $10 \mathrm{~cm}$ wide plate, the line with $\mathrm{R}$ represents the Raschke's result (1956), $D=5.0 l^{-0.3}$, with $D$ being the boundarylayer transfer coefficient including the buoyancy effect; G, Gates (1968), $D=3.78$ $l^{-0.35} ; \mathrm{B} \cdot \mathrm{C}$, Balding and Cunningham (1976), $D=4.43 l^{-0.53} ; \mathrm{H} \cdot \mathrm{I}_{1}$, present result, $D_{f}=3.60 l^{-0.5}$, which is equal to the theoretical value for forced convection $\left(D_{f, T H}\right)$; and $\mathrm{H} \cdot \mathrm{I}_{2}$, presnt result, $D_{f}=3.25$ $l^{-0.34}$.

For $1 \mathrm{~cm}$ wide plate, G, $D=8.07 l^{-0.35}$; B.C, $D=6.13 l^{-0.57}$; and $\mathrm{H} \cdot \mathrm{I}, D_{f}=4.53$ $l^{-0.34}$. the vapor ones.

The transfer coefficient obtained by Raschke (1956), being considered to be applicable for the leaf of a large width transverse to the air flow, is remarkably larger than the other ones (upper part of the figure). Although, for $10 \mathrm{~cm}$ wide leaf, the values of the coefficients by Gates (1968) are larger than those in the present work and by Balding and Cunningham (1976), the difference is rather small over a smaller length range than the width. But, over the larger length range, the difference becomes too large to understand. The transfer coefficients by Balding and Cunningham seem to include the buoyancy effect. When the buoyancy effect is subtracted from their coefficients, the results may show a good agreement with the present ones, for $10 \mathrm{~cm}$ wide plate. At larger leaf-length, however, their transfer coefficients approach to the theoretical value. Such a function is dominantly seen in the lower part of the figure for a plate with a narrow width. This is contrast to the present results and considered not to be realistic. For plates with narrow width and/or relatively small dimension, it is considered that the transport along the surface at the plate edge results in an increase in convective transfer coefficient more than the theory.

\section{References}

1) Balding, F. R. and Cunningham, G. L., 1976: A comparison of heat transfer characteristics of simple and pinnate leaf models. Bot. Gaz., 137, 65-74.

2) Gates, D. M., 1968: Transpiration and leaf temperature. Ann. Rev. Pl. Physiol., 19, 211-238.

3) Haseba, T., 1973: Water-vapor transfer from plant-leaf surface by forced convection with special reference to inclination of leaf. $J$. $\mathrm{Agr}$. Met., 29, 1-9.*

4) Haseba, T., 1974: Mass transfer across the boundary layer on plant leaves. (1) Preliminary study of water-vapor transfer from a leaf-like flat plate with separated evaporation sources. Jo Agr. Meto, 30, 45-55.

5) Haseba, T., 1975: Water-vapor transfer from fluttering leaves within a plant canopy. Field observations and laboratory experiments. $J$. Agr. Met., 31, 135-143.*

6) Haseba, T., 1977: Forced-convection watervapor transfer across the boundary layer on the flat leaf model of small dimensions. 
J. Agr. Met., 33, 75-79.*

7) Haseba, T. and Ito, D., 1976: Water-vapor transfer across the boundary-layer on rice leaf. I. Evaporation from wet surface of leafshaped plate in laminar air flow. J. Agr. Met., 32, $137-144$. $^{*}$

8) Monteith, J. L., 1973: Principles of Environmental Physics, Edward Arnold, London, 100-118 and 134-149.

9) Parlange, J.-Y. and Waggoner, P. E., 1972: Boundary layer resistance and temperature distribution on still and flapping leaves. II. Field experiments. Plant Physiol。, 50, 60-63.
10) Pearman, G.I.; Weaver, H.L. and Tanner, C.B., 1972: Boundary layer heat transfer coefficients under field conditions. Agric. Meteorol., 10, 83-92.

11) Raschke, K., 1956: Mikrometeorologisch gemessene Energieumsätze eines AlokasiaBlattes. Arch.Met。 Geophys., B7, 240-268.

12) Yabuki, K. and Harazono, Y., 1978: Studies on the effects of wind on photosynthesis. (7) The structure of boundary layer near leaf surface (II). J. Agr.Met., 34, 87-94.*

* written in Japanese with English summary.

\title{
植物葉面水蒸気輸送係数と葉寸法との関係
}

\author{
長谷場徹也・伊藤代次郎
}

(愛媛大学農学部, 松山市樽味3-5-7)

\begin{abstract}
要
約

平板状植物葉の強制対流による境界層水蒸気輸送係数 $\left(D_{f}, \mathrm{~cm} / \mathrm{s}\right)$ と葉寸法 $(l$, 長さ $; s$, 巾, $\mathrm{cm})$ との関係 を, 実験から求めた。葉の模型は, 片面を湿面とした矩 形平板で, これを風洞のテストセクション内で気流と平 行に扔き，蒸発量，湿面温度及び空気湿度の測定值から， 境界層輸送係数を求め, 乙れに, 浮力の効果を, 自由対 流輸送係数の計算值で近似的に補正し, 強制対流輸送係 数の面平均値を決定した。

層流条件下で得られた平均強制対流輸送係数は， $l \leqq$ $0.33 s^{1.6}$ の寸法範囲の面については, 理論值と一致し, 面の巾には関係しなかった。

しかし， $l>0.33 s^{1.6}$ の寸法範囲の面では, 輸送係数 の実測值 $\left(D_{f, O B S}\right)$ は理論値 $\left(D_{f, T H}\right)$ より大きくなり, $\alpha=D_{f, O B S} / D_{f, T H}$ とした補正係数は， $\alpha=1.20 l^{0.16}$ $s^{-0.26}$ 之求められた。すなわち, 上の範囲の寸法の葉面 亿適用すべき強制対流水蒸気輸送係数は， $D_{f}=0.797$ $S c^{1 / 3} R e^{1 / 2} d l^{-0.84} s^{-0.26}=0.43 u^{0.5} l^{-0.34} s^{-0.26}\left(20^{\circ} \mathrm{C}\right)$ で あり，面の巾の関数とあなる。乙てに，Sc, Schmidt 数; Re, Reynolds 数; $d$, 水蒸気の分子拡散係数 $\left(\mathrm{cm}^{2}\right.$ $/ \mathrm{s}) ; u$, 風速 $(\mathrm{cm} / \mathrm{s})$ である。
\end{abstract}

